\title{
Identification of business management improvement factors for start-up companies in Latvia in the conditions of globalization
}

\author{
Iveta Linina ${ }^{1, *}$, Dzintars Arbidans ${ }^{2}$, and Velga Vevere $^{3}$ \\ ${ }^{1}$ Turiba University, 68 Graudu street, Riga LV-1058, Latvia \\ ${ }^{2}$ Turiba University, 68 Graudu street, Riga LV-1058, Latvia \\ ${ }^{3}$ EKA University of Applied Sciences, 1/5 Lomonosova street, Riga LV-1019, Latvia
}

\begin{abstract}
Research background: Globalization trends are one of the main causes of global change in the world, and one of the most visible consequences of globalization is rapid market growth. In such market conditions, the focus must be on ensuring competitiveness. One of the key aspects of competitiveness is start-ups, which are sources of innovation and offer high value-added products, i.e. fast-growing and start-ups. Such companies play an important role in promoting economic growth and innovation in Latvia and Europe. It is essential to create a business ecosystem conducive to the further growth of these companies, including international cooperation, so it is important to ensure that these companies are given full access to start-up capital and adequate financing at all stages of the company's development and operation.

Purpose of the article: to determine preconditions and underlying factors for the formation of start-up companies.

Methods: A monographic or descriptive method was used to study the theoretical principles of start-up companies and the start-up situation in the Latvian economy, as well as expert interviews.

Findings \& Value added: As a result of the research, the aim of the research was achieved and the preconditions for the formation of start-ups and the main factors influencing their successful operation and development, which will allow the relevant state institutions and organizations to focus on them, were identified.
\end{abstract}

Keywords: start-up companies; business environment; product added value

JEL Classification: $M 13 ; O 3 ; O 36$

\footnotetext{
* Corresponding author: iveta.linina@turiba.lv
} 


\section{Introduction}

The development of civilization has always been based on the use of new knowledge and technology. Whether it is prehistoric methods of stones, metals, industrial, information revolutions, always new technologies, goods and services are the driving force of events that lead to an improvement in the quality of human life. In today's world, this algorithm of progress remains unchanged. In addition, there is a deeper understanding of the fact that the period of hope for extensive economic growth, growing resource scarcity and global climate change is over, and that innovation has a key role to play in ensuring economic progress.

The aim of the research is to look at and study the beginning of the activities of the startup support concept, the course of the process and the achieved results. The research paper analyses and researches the development of start-up over time from the beginning, when a support mechanism for start-up beginners was created to the current situation. Considering that start-up is a capital company with high growth potential, the main activity of which is related to the development, production or development of scalable business models and innovative products, the aim of the work is to determine the conditions that promote and hinder start-up development and make concrete proposals for improving the start-up business in the context of the regulatory framework and other factors affecting it. Tasks to be solved to achieve the goal: (1) to determine the theoretical aspects of the preconditions for the formation of start-ups; (2) to find out the place of start-up in the Latvian economy; (3) to analyse and determine the factors of successful start-up formation.

In order to achieve the set goals, a monographic or descriptive method was used, with the help of which the authors have studied the theoretical principles of start-up companies and the start-up situation in the Latvian economy, expert interviews identified factors for successful start-up creation and development. The research period was from 2020 to 2021. The experts invited in the study represent various business start-up areas. The methodological basis of the research is based on such theorists as D. Audretsch, A. Colombellic, L., D. Grilli, Hahn, T. Minola, K.A. Eddleston and others.

\subsection{Theoretical basis for the creation of preconditions for successful start-ups}

Innovative Start-ups can create and build new products and industries that result in significant economic and societal impact. In turn, the main preconditions for creating a successful startup are: an innovative and competitive idea, a supportive business and political environment, and the idea of skills and competencies to be successfully implemented (van Weele et al., 2018; Zhou and Verburg, 2020).

If we are talking about supportive policy environment, then in theory all national policy initiatives aim to promote start-ups, growth and innovation. In many countries, subsidies are considered for successful start-ups (Caliendo and Tublicke, 2021). only a few of them become high-impact companies. Thus, effective policies require a better understanding of the processes some start-up directions support. Evaluating the start-up and sustainability indicators of different countries in the context of a supportive policy and business environment, a "process framework" has been created to assess the stage of development of each start-up and the necessary state support policy in each of them. The proposed model provides insight into how new start-ups are classified to understand what support is needed (Audretsch et al., 2020). In this framework, it is proposed to evaluate each start-up from 4 positions: general or theoretical perspective, the essence of the start-up, the area in which the start-up will operate and the necessary policy initiative for this start-up. At the same time J. Potts (2016) points to the problem of absence of global coordination in innovation policy arising from strategic interactions between national innovation policies and to the fact that there are missing global institutions in this area. One of the possible solutions, i.e., 
development of a framework of the elements of the entrepreneurial ecosystem in the context of born global start-ups is proposed by Velt and others in their article "The entrepreneurial ecosystem and born globals: the Estonian context" (2018).

In each of these headings, the following indicators need to be assessed: - antecedents, funding characteristics, behaviour, outputs and impacts. The authors believe that with such a framework, policy makers would be better placed to evaluate the necessary support initiatives for the policy framework (Audretsch et al., 2020). Entrepreneurship is at high risk of failure in the changing context of globalization. The main difference between start-ups and other companies is that, in essence, these risks are reduced, because the factors that strengthen the positive growth trends are already laid in the foundations of start-ups. As well as start-up core business should be based on the principles of effective management (Linina et al., 2018).

As one of the preconditions for successful start-up is the dimensions of social capital and support, they promote the establishment of start-ups in the regions. For example, Riga startup perceives a high level of social support from family and friends. It is the Riga start-up that values social capital in all three dimensions - structural, cognitive and relationship (Bikse et al., 2018).

Researching successful start-up experiences reveals discussions about the involvement of scientists in start-ups. The team conducted a study on the commercialization challenges faced by start-ups and developed a framework that encourages researchers to engage in innovation in the context of entrepreneurship, thus providing added value in start-up development (Hahn et al., 2019). The study illustrates the benefits that a researcher can bring to a start-up company by promoting their careers, and the importance of involving researchers as founders in order for a start-up company to benefit from researchers and vice versa. It is emphasized that it is also important to change the researcher's previous experience and way of thinking and adapt it to a new context - the idea of commercialization and profit. In addition, the findings suggest that strategic planning and an emphasis on commercial objectives increase the positive impact of founder researchers on start-ups. It is emphasized that those start-ups that develop and link the scientific mindset with the business mindset will have greater advantages in the commercialization of innovation (Ibid.).

Regarding the Latvian context, the involvement of scientists in the development of startups is not yet widespread. Attempts by scientists to offer companies innovative products that are relevant to large global markets require large financial investments, as well as additional investments in marketing and local market research. Attempts to promote well-known products in foreign markets in Latvia, without taking into account the specifics of the market of specific countries, have not proved to be a method of successful expansion of start-up operations.

As a contributing factor in the development of start-ups, the literature also emphasizes the important connection with universities, therefore it is important to involve more students in the activities of university business incubators in Latvia as well. Universities also need to forge close links with competitive companies to help commercialize start-ups faster by creating innovative products not only in the local but also in the global market, thus developing into business universities. A study conducted in Latvia (Bikse et al., 2018) concluded that although financial support is an important factor in starting a business, at the same time young entrepreneurs need tax relief and the necessary infrastructure must be provided to ensure access to knowledge. and to develop entrepreneurial skills in secondary school / university.

Latvia is a small country, not only territorially, but also in terms of creative capacity. Therefore, when starting a start-up project, certain conditions must be taken into account in relation to innovative products created in Latvia. There are a number of ways to overcome obstacles and gain recognition from potential investors. For example, functional foods that are used to reduce health problems and are popular in many countries around the world. To 
get to the crowded shelves of European stores, you need to take actions that are not required by EU law, such as obtaining and indicating the scientifically proven effect of the product. Such information is attractive to product distributors and such products stand out from the range of analogous products. There are only a few food profile companies in Latvia that are ready to work in this way.

The quality of regulatory enactments is an important factor in the development of startups, as it regulates mandatory rules in the private law sphere. As an impediment to start-up growth, the impact of the environment on state institutions and the regulatory framework, offering a solution to create systematic business incubators (Homfeldt et al., 2020).

Following modern trends, start-ups that place more emphasis on environmental protection in value creation compared to economic value creation ("greener start-ups") are more innovative, as they are ahead of the so-called conventional innovative companies in their development. The regulatory framework for regulating environmental regulations at the national level can convincingly influence and facilitate these processes. Here, the essential difference between the creation of economic value (creation of private wealth) and the creation of value in environmental protection (societal benefits for the environment) must be assessed. The added value of a greener start-up is a social determinant and a compelling product sales story that attracts a certain and relatively affordable audience (Hoogendoorn et al., 2020).

\subsection{Description of start-up companies in Latvia}

The strategic importance of innovation has been emphasized in documents adopted by the EU institutions over the last 20 years. As a member state of the European Union, Latvia develops its regulatory documents within the framework of the general European strategy, taking into account the specifics of the local economic situation.

There are several documents, directives and regulatory enactments aimed at the development of innovations in Latvia, the main ones are the following: "Law on Aid for the Activities of Start-up Companies" (Legal Acts of the Republic of Latvia, 2017); Order No. 282 of the Cabinet of Ministers "On the Guidelines of the National Industrial Policy for 2021-2027" (Legal Acts of the Republic of Latvia, 2021); Cabinet of Ministers Regulation No. 193 "Procedure for Granting State and European Union Support in the Measure" Innovation "”" (Legal Acts of the Republic of Latvia, 2016), Regulation (Eu) No 508/2014 of the European Parliament and of the Council (Eur-Lex, 2014); Regulation No 1255/2011 of the European Parliament and of the Council (Eur-Lex, 2011).

However, at present, according to the conservative forecast of the Central Statistical Bureau, the results have shown that economic growth has slowed down or stabilized. Assessing what is happening in specific sectors of the economy - manufacturing, agriculture, construction, services, etc., there are no visible justifications or indicators to forecast a rapid growth rate. Assessing the data compiled by Eurostat on how much (as a percentage of GDP) EU countries spend on research and development, we conclude that in 2019 Latvia spent about $0.64 \%$ of GDP. Latvia leaves behind Cyprus, Malta and Romania. Another trend has been observed that Latvia's innovation leaders are companies with either $100 \%$ state capital or a significant state-owned share in their ownership structure (Eurostat, 2021). In the competitiveness index, Latvia lags behind Lithuania and Estonia.

A comparative assessment of the research and innovation performance of EU Member States and selected third countries, as well as the relative strengths and weaknesses of their research and innovation systems, is provided by the European Innovation Scoreboard (EIRP) commissioned by the European Commission. in which more needs to be done to improve innovation performance (European Commission, 2021). Based on these results of the evaluation of innovation activity, Latvia's place in the list of EU countries has been in the last 
places unchanged since 2018. And the result has also deteriorated compared to 2020, with Latvia, along with Bulgaria, Croatia, Hungary, Poland, Romania and Slovakia, being rated emerging innovators.

The evaluation methodology used in the European Innovation Scoreboard distinguishes four main types of action in 12 innovation areas and covers a total of 32 different indicators. The framework conditions are the main external drivers of business innovation and cover the three dimensions of innovation, namely human resources, the attractiveness of research systems and digitalisation. Investment takes into account public and private investment in research and innovation and covers three dimensions: finance and support, business investment and the use of information technology. Innovation activities characterize innovation efforts at the enterprise level and are grouped into three dimensions of innovation: innovators, collaboration and intellectual resources. Impacts cover the impact of companies' innovation activities in three dimensions of innovation: impact on employment, impact on sales and smart sustainability (European Commission, 2021). Sustainable start-ups should be based on forecasting the business performance of start-ups (Leendertse et al., 2021).

From the indicators assessed in this report, Latvia's competitiveness in the field of innovation is not improving in the European and global context, however, if we look at certain indicators that may also influence successful start-ups, in Latvia, for example, the availability of early stage funding has increased and increased. attract funding in the early stages of innovation. In such circumstances, investment funds have a greater role in start-up financing and the best accelerators are trying to move towards investment fund activities (Bonaventura et al., 2020). Associations of regional investors or business angel clubs are formed to concentrate resources. However, we believe that the state should provide more financial support for start-ups and innovation in general.

The authors believe that subjective opinions also have a price in creative, research work. Research "Assessment of the ecosystem of Latvian start-ups, identification of the current situation and development of proposals based on it", commissioned by the Ministry of Economics in 2019 (Gateway \& Partners, 2019). contains extensive information on the subject with an emphasis on innovation in the ecosystem.

\section{Methods}

Expert methods are increasingly used in the evaluation and forecasting of socio-economic processes. The expert survey is mainly used in diagnosing and forecasting industry problems and in analysing and solving research problems (Kristapsone, 2014). Unlike statistical methods, experts take into account a number of non-analytical factors due to their experience and knowledge of the start-up situation. The authors of the paper observed four stages in the implementation of the expert survey method.

1. Preparation of an expert survey. At this stage, the research problem was formulated and the aim of the expertise was clarified - the factors influencing the formation of start-ups.

2. Selection of experts and formation of the composition of the expert group. At this stage, the numerical composition of the expert group was determined, the analysis of the competence of the expert group was performed, and the experts were provided with the necessary information. The experts invited to the study are from various business areas related to the start-up area. Numerically, the level of competence of a potential expert was assessed according to a formula (Vasermanis et al., 2002). As a result of the selection of experts, a group of experts was formed, which included Uldis Manikas, Head of the Bauska Business Incubator and Start-up Project Evaluator of the Latvian Investment and Development Agency, Dmitrijs Babarikins, 
Head of the Institute of Innovative Biomedical Technologies, Howtostartup manager Edurd Baginskis.

3. Characteristics of the expert survey. The expert survey was conducted in JanuaryFebruary 2021. Based on the objectives of the expertise and taking into account the specifics of the experts, the authors of the paper chose the following characteristics of the expert interview: the experts participate independently of each other; and faceto-face in-depth interviews are conducted.

4. Expert evaluation processing and analysis. The answers of the expert interviews on the considered questions were summarized in the table and conclusions were drawn using the logical - constructive research method (Tobin and Begley, 2004).

\section{Results and Discussions}

The results of the expert interviews are presented in the Table 1.

Table 1. Factors influencing the formation of start-ups and promotion of activities in Latvia

\begin{tabular}{|c|c|c|c|}
\hline No & Question & Answer summary & Conclusion \\
\hline 1 & $\begin{array}{l}\text { Factors influencing } \\
\text { the formation of } \\
\text { start-ups and } \\
\text { promotion of } \\
\text { activities in Latvia }\end{array}$ & $\begin{array}{l}\text { Scientific development, } \\
\text { synergy with entrepreneurs } \\
\text { and educational institutions. } \\
\text { For this to happen an important } \\
\text { precondition is not only public } \\
\text { funding for science, but also } \\
\text { national ambitions, a focused } \\
\text { vision and focus on } \\
\text { digitization, STEM (Science, } \\
\text { Technology, Engineering, } \\
\text { Arts, Maths) education and } \\
\text { support for new entrants. } \\
\text { Start around formation is } \\
\text { unthinkable without the } \\
\text { availability of financing } \\
\text { locally and internationally, a } \\
\text { relaxed tax environment } \\
\text { (business incubators), clear } \\
\text { analysis of the market situation } \\
\text { and also market stability. } \\
\text { Funding can take the form of } \\
\text { start-up capital or the support } \\
\text { of ideas, which in general are } \\
\text { aimed at facilitating and } \\
\text { creating a suitable business } \\
\text { environment, which is also this } \\
\text { favourable ecosystem. } \\
\text { The last of the most important } \\
\text { factors is the idea of team } \\
\text { building and the most suitable } \\
\text { business model, the } \\
\text { appropriate environment and } \\
\text { time for the realization of the } \\
\text { idea. }\end{array}$ & $\begin{array}{l}\text { Strong and developed } \\
\text { education, science and its } \\
\text { synergies, as well as } \\
\text { international integration, } \\
\text { which enables the } \\
\text { emergence of young, } \\
\text { talented and competitive } \\
\text { authors and entrepreneurs. } \\
\text { An important factor is team } \\
\text { building, business idea, the } \\
\text { most suitable business } \\
\text { model and the appropriate } \\
\text { environment and time for } \\
\text { the implementation of the } \\
\text { idea. }\end{array}$ \\
\hline
\end{tabular}




\begin{tabular}{|c|c|c|c|}
\hline 2 & $\begin{array}{l}\text { Factors that need to } \\
\text { be improved and } \\
\text { developed to } \\
\text { encourage start-ups }\end{array}$ & $\begin{array}{l}\text { First, the geospatial location of } \\
\text { the country, the flight to Berlin } \\
\text { or Moscow is less than } 2 \text { hours. } \\
\text { It is a } 15 \text {-minute drive or taxi } \\
\text { ride from the airport to the } \\
\text { business centres and the } \\
\text { capital. Business premises are } \\
\text { of high quality and cheaper } \\
\text { than in the already mentioned } \\
\text { Berlin or Moscow, the rent and } \\
\text { availability of corporate } \\
\text { premises is also sympathetic. } \\
\text { And very important is the } \\
\text { coverage of } \\
\text { telecommunications and the } \\
\text { Internet throughout the country } \\
\text { and the price for its quality. No } \\
\text { less important is the unique } \\
\text { environment for living and } \\
\text { relaxing - a } 200 \text { km long white } \\
\text { sandy beach by the sea, a few } \\
\text { minutes drive from the city } \\
\text { centre, organic food grown by } \\
\text { local farmers, as well as cold- } \\
\text { skilled and cheap labour for } \\
\text { business in Europe. places. } \\
\text { There are currently several } \\
\text { start-up business environments } \\
\text { suitable for business } \\
\text { incubators, which are business } \\
\text { accelerators and business risk } \\
\text { insurers. }\end{array}$ & $\begin{array}{l}\text { There is a number of } \\
\text { important factors that need } \\
\text { to be improved and } \\
\text { developed to encourage the } \\
\text { creation of start-ups, while } \\
\text { there are already many } \\
\text { favourable and business- } \\
\text { friendly preconditions for } \\
\text { investors to invest capital } \\
\text { here and for new start-ups } \\
\text { to emerge. } \\
\text { Examples include Venture } \\
\text { Faculty, Altum and the } \\
\text { Investment } \\
\text { Development Agency of } \\
\text { Latvia. The agency also has } \\
\text { several support programs } \\
\text { for foreign entrepreneurs to } \\
\text { enter the Latvian market. }\end{array}$ \\
\hline
\end{tabular}

Source: authors'

Summarizing the answers provided to the questions in the expert interview, it can be concluded that strong, developed education, science and its synergies, as well as international integration provide an opportunity for new, talented and competitive authors and entrepreneurs. As well as an important factor is team building, business idea, the most suitable business model and the appropriate environment and time for the implementation of the idea. At the same time, there are already enough favourable and business-friendly preconditions in Latvia for investors to invest capital here and for new start-ups to emerge. Latvia does not yet have a global start-up, however, there are a number of companies that have successfully scaled their product / service and operate in international markets. The specifics of start-ups are very often not related to a specific field, but to a change in the business model, which means that in real life in a start-up country can develop in industries and areas where there are no advantages or traditions. This way start-ups can create a whole new industry. The Investment and Development Agency of Latvia also has several support programs for foreign entrepreneurs to enter the Latvian market. 


\section{Conclusions}

1. There is a link between the factors needed to create an ecosystem, funding from different sources and the contribution to the economy of cold value-added products, services and technologies.

2. The role of the ecosystem is particularly important for countries with evolving moderate innovation assessments. It is economic development that is a motivating factor for the improvement of the ecosystem. Organizations that make up the start-up ecosystem need to pay special attention to the funding and management of science. The focus on digitization, STEM (Science, Technology, Engineering, Arts, Maths) education and support for new entrants is essential.

3. By ensuring coordinate and guided interaction between scientists and entrepreneurs, a more probable success of the start-up project is achieved.

4. Significant process optimization aimed at creating a smart economy also requires a system of applied research funding.

5. The specifics of start-ups are very often not related to a specific area, but to a change in the business model, which means that in real life in a start-up country can be formed in sectors and areas where there are no advantages or traditions. This way start-ups can create a whole new industry. Green start-ups will play an increasingly important and important role in the structure of the ecosystem.

6. Successful start-up business creation is based on an entrepreneur who manages the latest business models that can be provided by relevant education and envisages the improvement of the education system both in the direction of STEM (Science, Technology, Engineering, Arts, Maths) and TED (Technology, Entertainment, Design).

\section{References}

1. Audretsch, D., Colombellic, A., Grilli, L., Minola, T., \& Rasmussen, E. (2020). Innovative start-ups and policy initiatives. Research Policy, 49(10), 1-14.

2. Bikse, V., Lusena-Ezera, I., \& Rivza, B. (2018). Innovative start-ups: challenges and development opportunities in Latvia. International Journal of Innovation Science, 10(2), 261-273.

3. Bonaventura, M., Ciotti, V., Panzarasa, P., Liverani, L, Lacasa, L., \& Latora, V. (2020). Predicting success in the worldwide start-up network. Scientific Reports, 10, Art. No. 345.

4. Bonaventura, M., et al. (2020). Predicting success in the worldwide start-up network. Scientific Reports, 10, Art. No. 345.

5. Caliendo, M., \& Tublicke, S. (2021). Design and effectiveness of satrt-up subsidies: Evidence from a policy in Germany. Economic Analysis and Policy, 70, 333-340.

6. Eur-Lex. (2014). Regulation (Eu) No 508/2014 of the European Parliament and of the Council on the European Maritime and Fisheries Fund and repealing Council Regulations (EC) No 2328/2003, (EC) No 861/2006, (EC) No 1198/2006 and (EC) No $791 / 2007$ and Regulation (EU) No 1255/2011 of the European Parliament and of the Council. https://eur-lex.europa.eu/legal-content/EN/TXT/?uri=celex\%3A32014R0508

7. Eur-Lex. (2011). Regulation No 1255/2011 of the European Parliament and of the Council. https://eurlex.europa.eu/LexUriServ/LexUriServ.do?uri=OJ:L:2011:321:0001: 0010:EN:PDF 
8. European Commission. (2021). Directorate-General for Internal Market, Industry, Entrepreneurship and SMEs, European Innovation Scoreboards. https://ec.europa.eu/growth/industry/policy/innovation/scoreboards_en

9. Eurostat. (2021). https://ec.europa.eu/eurostat/web/products-eurostat-news/-/ddn20201127-1

10. Gateway\&Partners. (2019). Latvijas jaunuzñèmumu ekosistēmas novērtēšana, pašreizējā stāvokḷa identificēšana un uz tās balstītu priekšlikumu izstrāde. (d.nr. EM 2018/58).

18 jaunuznemumu_petijums 1

11. Hahn, D., Minola, T., \& Eddleston, K. A. (2019). How do Scientists Contribute to the Performance of Innovative Start-Ups? An Imprinting Perspective on Open Innovation. Journal of Management Studies, 56(5), 895-928.

12. Hoogendoorn, B., Van der Zwanb, P. \& Thurik, R. (2020). Goal heterogeneity at startup: are greener start-ups more innovative? Research Policy, 49(10), Art. No. 104061.

13. Homfeldt, F., Rese, A., \& Simon, F. (2019). Suppliers versus start-ups: Where do better innovation ideas come from? Research Policy, 48(7), 1738-1757.

14. Kristapsone, S., Kamerāde, D. (2011). Ievads pētniecībāa: stratēgijas, dizaini, metodes. RaKa.

15. Leendertse, J., Van Rijnsoever, F. J., \& Eveleens, C.P. (2021). The sustainable start-up paradox: Predicting the business and climate performance of start-ups. Business Strategy and the Enviroment, 30(2), 1019-1036.

16. Legal Acts of the Republic of Latvia. (2016). Procedure for Granting State and European Union Support in the Measure “Innovation ”. https://likumi.lv/ta/id/281357valsts-un-eiropas-savienibas-atbalsta-pieskirsanas-kartiba-pasakuma-inovacija

17. Legal Acts of the Republic of Latvia. (2017). Law on Aid for the Activities of Start-up Companies. https://likumi.lv/ta/en/en/id/287272

18. Legal Acts of the Republic of Latvia. (2021). On the Guidelines of the National Industrial Policy for 2021-2027. https://likumi.lv/ta/en/en/id/321037

19. Linina, I, Vevere, V., \& Zvirgzdina, R. (2018). Six Sigma Application Analysis in Small and Medium-Sized Enterprises (SME) In Latvia. Proceedings of 4th International Conference on Lifelong Education and Leadership for All (ICLEL) (pp. 602-6011).

20. Potts, J. (2016). Innovation policy in a global economy. Journal of Entrepreneurship and Public Policy, 5(3), 308-324.

21. Tobin, G. A., \& Begley, C. M. (2004). Methodological rigour within qualitative framework. Journal of Advance Nursing, 48(4), 388-396.

22. van Weele, M., van Rijnsoever, F.J., Eveleens, C.P. et al. (2018). Start-EU-up! Lessons from international incubation practices to address the challenges faced by Western European start-ups. Journal of Technology Transfer, 43, 1161-1189.

23. Vasermanis E., Šķiltere D., \& Krasts J. (2002). Prognozēšanas metodes. Latvijas Universitāte.

24. Velt, H., Torkkeli, L., \& Saarenketo, S. (2018). The entrepreneurial ecosystem and born globals: the Estonian context. Journal of Enterprising Communities-People and Places in the Global Economy, 12(2), 117-138.

25. Zhou, Z., \& Verburg, R. (2020). Open for business: The impact of creative team environment and innovative behaviour in technology-based start-ups. International Small Business Journal: Researching Entrepreneurship, 38(4), 318-336. 